\title{
THE EUROPEAN UNION: THE BUILDING OF A NATION
}

\author{
David Ramiro Troitino \\ Department of International Relations, Faculty of Economics, Tallinn \\ University of Technology, Tallinn, Estonia
}

CMESTE

JEL Category: Z12, Z13, Z18

\begin{abstract}
The European Union is an organization in a constant evolution with periods of stagnation. It has recently achieved high levels of integration that logically will be followed with a greater political integration. The Union will need a higher identification of the citizens in terms of participation in the democratic process and in terms of loyalty to the still to build the political structure. This research focuses on the actions undertaken in order to create a new level of identity, a European nation, by the actors involved in the European building process. It identifies the actions in two different kinds, the direct actions focus on this achievement and the indirect actions increasing the feeling of cultural communality in Europe. The direct actions follow the pattern already created by the European states creating their own nations, as establishing common symbols, convergence in the educational field, a common currency or a free movement area. The indirect actions normally do not have the involvement of the EU institutions, but also influence the process, as a sport, especially a football, Eurovision or the Council of Europe. The research proves an active policy integrating the Europeans but also points out problems and solutions for the success fulfillment of the process.
\end{abstract}

Keywords: The European Union, European Nation, European politics, European democracy, European integration.

\section{INTRODUCTION}

Europe is a complex idea based on different factors like geography, culture, politics, religion or economy. Geographically Europe is defined with its continental northern border of North Cape, Norway, the Cape Matapan in Greece, the Atlantic Ocean in the West and the Ural Mountains in the east. Geography is important because for joining the EU the candidates must be located

Address of the author:

David Ramiro Troitino

拝三" david.troitino@ttu.ee geographically in Europe, but Cyprus, a member of the organization, is clearly a country located in Asia, but its insularity and its Greek cultural heritage have influenced the inclusion of an exception to the rule above mentioned. Despite the fact that $20 \%$ of the territory of Kazakhstan is located westwards from the Urals, on the European soil, there is no debate about the Europeanism of the country. Turkey, with a small percentage of its territory in Europe, has generated an endless debate about if the country belongs to Europe or Asia because being a bridge between both areas (as commonly mentioned) will close its participation in the European integration. 
On the north, Iceland is generally accepted as Europe from the geographical point of view, but Greenland generates more controversy about its belonging to Europe or America. Geographically another conflictive area is the Caucasus region, where Georgia, Armenia, and Azerbaijan are not fully accepted neither as Europeans nor as Asians (Kaelble, 2003). Finally, Russia and its double soul, belongs somehow to its own particular geographical area, not Europe, not Asia, as most of its territory belongs to Asia but most of its population lives in the European territory of the federation.

Culturally the borders of Europe are more flexible. Obviously the spiritual soul of Europe springs in the Ancient Greece, as the philosophical ideas of Plato and Aristoteles have shaped the European culture and our way of thinking, Thucydides created history as we understand it, Phidias shaped our taste for art, or the influence of Euripides in our literature standards, among others outstanding artists. Freedom and individuality empower by the concept of citizenship in opposition to other social structures, as the oriental absolute power, influenced also the development of Europe (Chochia, 2012, 27).

Religion, Christianity, has helped to shape the European cultural values, as solidarity, but also with the religion wars to liberate Europe from Muslim rule in different territories as Spain, Sicily or the Balkans; the expansion of Europe eastwards to pagan lands to Christianise the population; the conflict between laicism and the Christian church, with the involvement of the Pope in earthly affairs rather than spiritual matters during centuries; several religion wars in Europe facing different Christian groups, and the culmination of the process with the incorporation to the European identity of the principles of the French Revolution, the separation of politics and religion, material matters under the rule of the state, spiritual affairs under the Church. The laicism is a European creation and part of the European identity (Bruter, 2005). Therefore, the Christian roots of Europe are obvious, but its laicism makes possible to other religions to cohabitate peacefully in Europe as long as their believers accept the separation between public and spiritual affairs, a concept sometimes not truly understood. Religion creates some suspicions among many Europeans in the case of Turkey, a predominantly Muslim country, because of the importance of the religion in the organization of the society and its impact in the public life (Kohli, 2000, pp. 113-137). On the other hand, other European countries with fairly large Muslim populations", do not generate any conflict because of their religion.

In terms of politics, democracy is the dominant model of organization of the state in Europe with its roots in the Athens of Pericles. It is also a requirement to join the European Union. Hence border countries as Belarus are currently not fully accepted as Europeans because, among other reasons, its political system.

The market economy is an important factor of the European identity, and also another requisite to join the European Union.

The social structures of Europe are also an important part of its identity, as the concept of society is strongly linked with the idea of the nation, being most of the European countries national states, or at least with a predominant national group dominating the political structures of the society. The social cohesion in the European states come mostly from the identification of nation and state. On the other hand, most of the world is mostly organized on a different basis as often nations are kept in the cultural sphere without influencing the political life. Nevertheless, the European organization of nations has been imitated, especially in America, with the creation of nations by their respective political states.

The social system, respect to human rights or the role of women in the society, health care system, are other characteristics of the European civilization.

Hence, the concept of Europe is a complex system of a variety of factors that make Europe flexible in time and space, being its borders temporal. It generates tensions in the European Union because of internal reasons, the social cohesion or identity among Europeans, and externally, as the limits of the organization cannot be withdrawn clearly (Amin, 2004, pp. 1-14). 


\section{THE EUROPEAN UNION}

The European conflicts during the XX century devastated Europe and were spread all over the world. Nationalism and aggressive behavior against other nations were the main causes of the conflict. Already Kant in his Perpetual Peace mentioned this source of conflicts, pointing out a solution based on a European federation. Aristide Briand, who served several terms as Prime Minister of France during the French Third Republic, presented a plan with the collaboration of Stresemann, German foreign minister of the Weimar Republic, to create a European organization overcoming the national boundaries of its members to avoid future conflicts (Kerikmae, 2009). The British promoted the creation of the League of Nations, as a forum where the world could solve the conflicts by peaceful means. The national sovereignty of the member states was fully respected in the organization. This approach is fully understandable through the prism of the British Empire, the biggest and more powerful of the world, with the English nation ruling over other hundreds of nations. Nevertheless, the League of Nations proved to be powerless stopping or preventing different conflicts, especially the rise of Japanese, Italian or German imperial nationalism leading to the IIWW.

Once again, the war was a direct consequence of the aggressive behavior of several nations rather than an ideological conflict, as the alliance between USA and USSR (Kirch, 2004, 38-40), or the different behavior of the German occupation forces in areas like Norway or France and Yugoslavia or Russia. Nationalism was to be blamed for the conflict by Altiero Spinelli in his Manifesto per Europe. Jean Monnet wanted to overcome the national differences among the Allies, Salvador de Madariaga presented the national differences as the cultural wealth of Europe, but a political curse. It is remarkable their defense of the different national identities in the cultural level, seeing the nations as something precious to be kept and enjoyed, but insisting on the separation of culture and politics; nation and state.

The main options in the process were adding a new level of identity above the national-state level functioning as a Matryoshka doll, or building a new political society centered in the political rights rather than the national issues: citizenship against nationality. The path initiated by the first European Community, the European Coal and Steel Community, was a hybrid solution, a new community based on political rights, equality of the members, with a high potential for developing a new national identity at the European level.

There are two main schools dealing with national states or the merger of politics and cultural identity, the French and the German. The second believed in the idea of the existence of the nation before the state; afterward, the nation provides itself with political institutions, as we can see in the Addresses to the German Nation (Reden an die Deutsche Nation, 1808) by German philosopher Johann Gottlieb Fichte. The concept of Volkgeist, or spirit, or soul of the folk is understood as something autonomous from the humans forming it; the Volkgeist as something that is alive, needs to be cared of, needs to grow, needs to develop. The best way to fulfill these necessities is providing the society with a political structure, the nation creating the state. On the other hand, the French tradition prioritizes the State over the nation, believing that the state is the spring of the nation, as unifying standards promoted by the state can increase the cultural similarities among the subjects in the territory, increasing the convergence of the cultural groups included in the state, and hence, creating the nation.

The European integration process is a hybrid system, where the integration started with the economy, leading to a closer political approach. Nevertheless, in the Schuman declaration, the target of the creation of the United States of Europe is clearly included as the most desirable target of the integration in Europe. The integration has followed in many cases the neo-functionalism approach, especially the spill over effect (Troitino, 2013 , p. 9). The pattern is based on integration in areas of low politics, where the public opinion is not a concern and hence the public resistance to the process is minimal, avoiding conflicts. The integration in these areas provides benefits, and more involvement in the process of those obtaining the benefits, but also new problems that normally can be solved just with deeper integration or dismantling the previous integration. It is a continuous process that theoretically will include more and more fields in the sphere of 
influence of the European integration, including also political aspects at the end of the process, fields with an important link to the public opinion and democracy. The previous integration would have included most of the economic areas, attracting to the supporters of the European integration all the economic and political actors involved in the project. (Troitino, 2010, p. 87) Following this theory, the European States of Europe would be a must for the European Union in order to avoid the collapse of the organization and to protect the already integrated fields and would be supported by the European citizens as the best and more rational option.

The model has worked astonishingly well in the economic field, but it is generating political problems, specifically a lack of identification by the European citizens with the project. The transfer of sovereignty from the state level to the European level has been successfully achieved in many fields, but the direct cession of sovereignty from the citizens to the European level shows a democratic deficit as the participation in the European elections is always far below the participation in the national elections. The rationality of the neo-functionalism theory clashes with the emotional identification of the people with the European project; a democratic system cannot survive without the support of the members of the society; the citizens.

The lack of interest of the European citizens in the European Union is linked with the absence of a strong common identity. Obviously, there is a European identity and it is growing, but the late expansion of the Union has made it more diffuse in a moment when the organization is reaching the cultural borders of Europe and the political integration is growing. Countries as Serbia, Montenegro, Bosnia and Herzegovina, Macedonia or Albania do not generate many problems in the cultural level of further integration in the organization, as they are widely accepted as Europeans and shared most of the common values of the member states. Even though Europe is a cultural mosaic, there is a common set of values widely accepted by the European people. The main concern is related to their capacity to adopt the European socioeconomic model. On the other hand, Belarus and Ukraine, are more problematic, because of the influence of the
Russian world, a different civilization strongly linked with Europe but having its own identity. The case of Ukraine is more problematic as the country itself is divided between Russian and Western influences. The problem of common identity grows more concerns in the Caucasus area, and the Georgian dream of becoming a member of the European Union. Other countries as Armenia or Azerbaijan could also claim membership in the European Union if Georgia will succeed in its European aspirations, increasing the lack of common identity and decreasing the possibilities of political integration at the European level. The case of Turkey is the maximal exponent of this conflict, as for centuries the Ottoman Empire was seen as an occupation force in Europe and its society model differs in major issues with the European standards. The problem is not linked with religion, as many Muslims are already living inside the European Union, or Albania and Bosnia and Herzegovina will, most probably, become members of the Union in the future, but with the influence of religion in the public life, clearly against the European laicism tradition, the role of women in the society, the freedom of speech, and other European cultural aspects clearly different in Turkey. It is not a competition to define what is better or worse, or a matter of European discrimination against Turkey, rather than common values basic to build a common political structure. If the Turkish society feels unease with these values promoted by Europe, it should follow its own way to achieve a harmonic society. Nevertheless, as already mentioned, the borders of Europe are flexible, and the situation could change in the future. Turkey was implementing laicism and other Western reforms since the time of Mustafa Kemal as a state policy, but currently, the process is being reversed by a government elected democratically. It is including more and more religious elements as a way to fulfill the ideological, cultural and religious demands of the Turkish, those citizens who chose the government in free and fair elections. Nevertheless, there is still and important part of the population closer to the European standards, but currently they are a minority in the country. Turkey must choose its way, laicism and European standards in human rights, role of women in the society, equal treatment of the citizens or no discrimination of the minorities, educational model, or on the other 
hand a society based on the principles of Islam, more traditional, with more influence of the religion in the public life, and perhaps more suitable for the Turkish population according to the electoral results in the last 20 years.

The internal sphere of the EU in terms of cultural identification is basically linked with two options; to keep on the integration process, because the tensions of the current system can be just solved with deeper integration, or dismantling the already integrated policies bringing them back to the national control. The integration possibility includes more political aspects until the full integration represented by the European States of Europe against a more economic approach, based on a British concept of free trade area without political integration link with political cooperation. This option already was followed by the European States included in the European Free Trade Association, or by United Nations in political terms, without the same level of success of the European Union. Countries as Turkey could easily join an organization based on free trade and political cooperation even if its citizens opt for a model of society different from the European tradition, but if the option chosen in Europe follows the path of deeper political integration, future members of the Union must share a common major identity with the rest of the members.

Hence, the enlargements of the European Union are in a crucial stage generating tensions inside the European Union and among the possible candidate countries. The process will be defined in the coming years by the model of organization chosen by the member states, currently the main actors in the process (Risse, 2003, 487-505).

There is another formidable obstacle to the creation of a strong common identity among the European citizens, nationalism. Europe is the birth land of political nationalism; its geography has allowed an important cultural diversity and the creation of numerous cultural groups or nations. Europe developed the idea of the identification of the nations with the political state, merging the cultural and political spheres, and exporting it to the rest of the world (McLaren, 2006). The aggressive behavior of the national political states in Europe was understood as the main reason for the IIWW by outstanding European intellectuals, as Altiero Spinelli, politicians, as Robert Schuman, philosophers as Ortega y Gasset, and policy makers as Jean Monnet. The best proposal to overcome the conflicts generated in Europe was breaking the identification between nation and politics. Nevertheless, nationalism is still nowadays seen as the main source of social loyalty from the citizens towards the state because it is based on feelings and ideas, providing a strong cohesion to the society, and hence strong support to the political state. The lack of European national identity is one of the reasons of the low cohesion in social terms in Europe, and a handicap for the so much needed popular support of the European people to the European integration process, as it is based more on a rational approach rather than feelings and emotions.

\section{THE EUROPEAN STATE AND THE EUROPEAN UNION INSTITUTIONS}

The first European Community, the European Coal and Steel Community, created the skeleton of the current European institutions. The original target included in the Schuman declaration of a future European state was included in the structure of the institutions with an executive power, the High Authority (currently the European Commission), independent judicial system (High Court of Justice) and a bicameral legislative power with a Common Assembly (The European Parliament of the EU) and a Council where the member states would be represented.

These first institutions were to be developed in a process leading to a supranational entity able to overcome the divergence among the nations involved in the integration process. Hence the Common Assembly was merely an advisory body without direct representation, but has evolved to a real parliament elected by the citizens in the European elections and a powerful institution in the decision-making of the European Union that in most of the legislative procedures stands in equal terms with the Council (Troitino, 2014, p. 15). The representation of the member states and its power has followed the opposite direction, reducing its influence in the European affairs or at least sharing its power with the European parliament and decreasing the power of the individual states transforming the voting system inside the Council from unanimity (Full sovereignty and 
independence for each state) to qualified majority (sharing the sovereignty with the other members of the Council).

The Court system also has been developed from a tribunal based on the economic field of Coal and Steel to a system of different tribunals that are influencing the life of all the Europeans with their decisions, applied in all the member states and prevailing over the national legislation.

Other former institutions, as the Consultative Committee (similar to the current Economic and Social Committee), pretended to bring closer to the European integration the civil society of the member states, but have declined and currently have no real power in the institutional framework of the European Union. Nevertheless, new institutions have been created to fulfil the necessities generated by the integration, as the European Central Bank, the European Court of Auditors, the European External Action Service (EEAS), the Committee of the Regions, the European Investment Bank, the European Investment Fund, the European Ombudsman, the European Data Protection Supervisor and some Interinstitutional bodies and Agencies of the EU. But they are not the last European institutions as the integration will follow deepening and more institutions will be required in order to manage commonly the new areas under the influence of the European Union.

Obviously, the current institutional framework of the European Union cannot be equated with the institutions of a State, but its development proves a growing power and higher capacity influencing the European population. (Troitino, 2014, pp. 3741)

Following the French model of nation state, where the state somehow creates the nation or is a driving force in the process of national integration, these European institutions could solve the problem of lack of support of the European citizens to the European Union promoting the creation of a common identity in Europe, creating the nation from the top, rather than the German model of the nation creating the State, the creation of the state from below. There is a palpable opposition from the national state level to accept this process as it is seen as a threat to the different national identities of Europe and an artificial movement to break to cohesion of the diverse national identities of Europe, but if we accept the premises of the French model, the nations have been created by the political power, and hence the creation of the European nation will be a natural process consequence of the political integration and growing power of the organization (Hedetoft, 1998). Also, against the local nationalist prejudices, the European nation has been presented as an addition to the current national identity of the Europeans rather than a substitute; national identities are to be respected as a primary element of a higher level of identification following the model of the Matryoshka dolls. The Europeans often have a local identity complemented by a regional identity, part of a wider national identity that could create a new level, the European identity. Obviously, a minimum common understanding among the nations is needed in the process, but we can find it in Europe as different pillars of the European civilization already mentioned in the introduction of this research, as democracy, human rights, laicism, equality, no discrimination, etc. This new level of identity could provide the European integration with the popular support it lacks currently, making the process more democratic and obtaining the loyalty of the citizens and more participation in the process.

\section{THE BUILDING OF THE EUROPEAN IDENTITY}

The Schuman declaration included in the targets of the European building process the creation of a European federation, but also pointed out the necessity to develop the process step by step, in a continuous growth. Since them, different measures have been undertaken in order to build the needed common identity following the French model where the political structure of the society provides elements for the internal cohesion of the population. These actions can be divided into two main groups, direct measures implemented by the European Union and indirect actions from other organizations influencing the process of common European identity.

\subsection{Direct actions}

The most visible initiatives in the field of the European identity are the European symbols created to become an icon for all the European 
Union citizens, representations to be felt as a belonging of all the Europeans regardless their nationality. The development of these symbols has not been a very creative process as it has followed the pattern established before by most of the European national states; it is an obvious process of imitation with the intention of obtaining similar results. The most visible symbol is the European Union flag, a circle of 12 gold stars on a blue field, providing common identification for all the Europeans and increasing the international presence of the EU in the world (Bruter, 2003, 1150). The European flag was not included in the European treaties, but was adopted by the EU Council, and afterward by the rest of the European institutions, including the EU Parliament. Its design, based on stars representing all the member states of the Union, resembles the flag of the United States of America. The European flag is also used by the Council of Europe, an institution not belonging to the European Union, providing a wider European perspective to this symbol. It also has been used to represent Europe in sports events increasing the commonality of Europe, as the Ryder Cup. The flag as a symbol is a success as most of the Europeans recognize it, and somehow feel some attachment to it. The flag also has been widely accepted as a European symbol, implying the cultural values of Europe, as democracy, as the use of the European flag during the Maiden protests in Ukraine showed.

The European anthem is another symbol created to unite the Europeans, again following the model of the national anthems of the national states of Europe. The melody used to symbolize the EU comes from the Ninth Symphony composed in 1823 by Ludwig Van Beethoven, when he set music to the "Ode to Joy", Friedrich von Schiller's lyrical verse from 1785 . This anthem pretends to express the European ideals of freedom, peace and solidarity, the common values of all the Europeans (Bruter, 2004). It is identified with Europe by most of the Europeans providing the feeling of belonging to the same community.

The European Capital of Culture is a city designated by the European Union for a period of one calendar year during which it organizes a series of cultural events with a strong European dimension pretending to share and spread the cultural aspects of all the Europeans increasing the common cultural consciousness. The European Union does not have a capital city, imitating the national states, where the capital plays an important integration role as the common space of all the citizens belonging to the state, as the EU institutions are located in three main locations, Strasbourg in France, Luxembourg, and Brussels in Belgium. However, there have been initiatives to relocate the main institutions in Brussels, a city that in the European popular imagination works as the capital of Europe.

Other symbols created are not widely known by the Europeans, and hence, are not properly working as an emblem uniting the European people in a common ideal. The European day, $9^{\text {th }}$ of May, the day of the Schuman declaration, represents a common festive of all the Europeans, as the national days in the member states. But the festivity is unknown by most of the EU citizens. The popular power of the event celebrated, a speech in Paris, cannot be compared with the emotional strength of the national days, as in the case of Spain Christopher Columbus's first arrival in the Americas, the French celebration to the Storming of the Bastille and the French Revolution, the day of the West and East reunification in Germany, or the many independent days in other European states, as for example Estonia. The exception is the United Kingdom, without a common national day, but the birthday of the queen, another national symbol, performances the same function. As the possibility of a European monarchy is a utopia it is more likely to change the European national day to some other day with higher emotional charge, as the $8^{\text {th }}$ of May, the end of the IIWW. The idea is not farfetched because the former European day was celebrated the $5^{\text {th }}$ of May commemorating the foundation of the Council of Europe.

The EU motto, „United in diversity", first came into use in 2000 and is and is little known to Europeans. Its meaning is obvious and represents properly the European building process, but its power as a symbol is negligible because it lacks symbiotic influence. The French motto, Liberty, equality, fraternity or the USA in God We Trust, have become symbols uniting the people and are internationally known; The European Union motto must be more actively promoted in order to archive its original function. 
The so-called Fathers of Europe, as Konrad Adenauer (Germany), Joseph Bech (Luxembourg), Johan Willem Beyen (Netherlands), Winston Churchill (United Kingdom), Alcide De Gasperi (Italy), Walter Hallstein (Germany), Sicco Mansholt (Netherlands), Jean Monnet (France), Robert Schuman (France), Paul-Henri Spaak (Belgium) and Altiero Spinelli (Italy), do not have the power of other national symbols, as George Washington in the USA, Mustafa Kemal in Turkey or Mahatma Gandhi in India. Even Churchill, included as a European symbol, is mostly known as an icon of the British nationalism, a dichotomy which shows the weakness of this symbol. The impossibility of choosing a common icon for the whole Europe because of their low identification with Europe, as for example Julius Caesar, or their implication in European wars, as Napoleon, makes extremely difficult to use the symbol of the father of the nation to unite the European people (Delanty, 1997, 290296). The role of European person representing all the citizens could be a cultural person, as Einstein, Shakespeare, Picasso, Leonardo Da Vinci, but their attraction as a European symbol is reduced by their universality, as they are symbols of the whole humanity.

In political terms, the European citizenship is an important milestone as it enforces the idea of the European Union as a common political entity, a supranational organization. The EU citizenship was introduced by the Maastricht Treaty (1992) as a supplement to the state citizenship, following the same model of Matryoshka doll proposed for the creation of a European common identity, adding a new level respecting the lower levels of identity. The main rights of the EU citizenship (Eder \& Giesen, 2001) are voting in European elections and local elections in any member state, the right to free movement, settlement, and employment across the EU, and the right to consular protection by other EU states' embassies when a person's country of citizenship does not maintain an embassy or consulate in the country they need protection in. The concept of common citizenship is strongly linked with the idea of a European federation where the subjects are the members of the society holding political rights, no matter their nationality. It is a powerful tool creating the European identity but its effects are mostly felt by those Europeans living in another state of the
Union, a small percent of the total population of the European Union.

The general principles of European Union Law provide a common set of rules for all the Europeans. The empire of Law is part of the European common identity coming from the Roman Empire contribution to the Europeanisms. It also gives legal certainty to the Europeans, as the same rules applied in their respective states are also implemented in the rest of the members of the Union. Hence, the creation of EU law provides and an important signal of commonality in Europe. According to the European Court of Justice, these rights are fundamental rights, proportionality, legal certainty, equality before the law and subsidiarity. The general principles are complemented by the European Union law, based on regulations and directives, which have direct effect or indirect effect on the laws of European Union member states. The supremacy of the EU law over the national legislation creates the idea of a higher legal entity, establishing same rights and duties all over the territory of the Union.

The Schengen agreement, originally an international treaty signed by France and Germany outside of the European Treaties, and hence outside of the influence of the European Union, was designed as a free movement of workers complementing the European market and the economic relations between these two countries. Nevertheless, soon it included more European countries till the majority of the member states of the European Union were also participating in the Schengen area. (Atger, 2008) The Amsterdam Treaty incorporated it into European Union law while providing opt-outs for the only two EU member states which had remained outside the Area: Ireland and the United Kingdom. Beside its original economic reasons, the Schengen area has had a big impact in the European common identity as it abolished the internal borders of the Union with external border controls for travelers entering and exiting the area. It works like a single state in terms of movement of people eliminating the psychological state borders; (Pascouau, 2011) the fact of crossing a border controlled by the national authorities increased the feeling of being abroad, being in other territory outside of the motherland opposite to the idea of no control inside the European Union 
encouraging the feeling of being in the same territory, of being still at home (Bertozzi, 2008). The increasing number of trips and movement of people inside the common European area has spread this feeling of a common entity to an important part of the European population (Grabbe, 2007, 530). It has become a very important tool creating the common European identity eliminating a traditional barrier link with the nation-state.

The common currency, the Euro was meant as a complement to the European market in order to abolish restrictions to trade created by the instability of the national currencies and the uncertainty affecting the European trade relations. The force of the common currency as a symbol of the union is very strong (Risse, EngelmannMartin, Knope, \& Roscher, 1999, pp. 147-187). The currency has been used as a propaganda item since the first civilizations, promoting common values and including common symbols in the coins as a way to integrate the whole territory included in the same economic system. The numismatic of the Roman Empire is a clear example of it, including the effigy of the emperors and their family as a figure uniting the empire under a common authority (Maguire, 1999, 17-29). The national states used this powerful symbol incorporating the national currencies as a basic step to achieve the national unity. The Euro has generated economic problems as the loose of financial autonomy by the national authorities without a realistic alternative at the European level and still needs reforms to work effectively. But from the national point of view, from the feeling of belonging to the same community has been extremely effective. The fact of using through most of the territory of the European Union the same currency is giving the European citizens a common identity, a feeling of being in the same territory (Bauboeck, 1997). The common design of the euro notes includes common symbols generating a common feeling, are based on architectural styles and ages developed in Europe and influencing all the European states. For example, the 5 euro note has a generic rendition of Classical architecture, the 10 euro note of Romanesque architecture, the 20 euro note of Gothic architecture, the 50 euro note of the Renaissance, the 100 euro note of Baroque and Rococo, the 200 euro note of Art Nouveau and the
500 euro note of modern architecture. The election of these symbols was based on their power of transmitting a common past and to reduce a rejection by the public opinion through the ethereal political implications of architectural styles. The Euro coins have their obverse designs chosen nationally, while the reverse and the currency as a whole is managed by the European Central Bank. The original design of the $€ 0.01$, $€ 0.02$, and $€ 0.05$ coins showed Europe's place in the world as a whole. The $€ 0.10$ coins and above showed either the 15 countries that were the European Union in 2002 or if minted after 2007, the whole European continent. (Luna-Arocas, 2001, 447-449) The national side includes national symbols, but there are, however, some restrictions on the design: it must include twelve stars. Nevertheless, the psychological importance of the Euro is more important than anything else, the fact of using the same currency in other states of the Union provides a strong common feeling to the Europeans living under the Eurozone.

Education is a fundamental pillar according to the French approach to the creation of the nation from the state. The European Union has developed different policies in the field of education influencing the Europeans and providing them with a sense communitarian identity based on common values (Kaelberer, 2004, 161-167). The main initiatives of the Union have focused on higher education, with the creation of the Erasmus program and the Bologna process. The Erasmus program under its different names is based on university student mobility all over the territory of the European Union. It has been a great success as more than 3 million Europeans students have enjoyed the program and its numbers are growing exponentially with its popularity (Souto-Otero, Huisman, Beerkens, De Wit, \& Vujic, 2000, pp. 7077). The political scientist Stefan Wolff has argued that in 25 years' time Europe will be run by leaders with a completely different socialization; the socalled 'Erasmus generation', a European generation. The most popular countries reviving Erasmus students are Spain, France, and Germany, western European states, the same countries send out more students under the program (Teichler, 2001, 201-227). The highest increase in out-bound students was noted in Croatia $(+62 \%)$, which joined the Programme in 2009-10. It was followed by Denmark $(+20 \%)$, 
Slovenia and Turkey (+17\% each). 11 countries experienced a growth above the average of $8.3 \%$. The program, among other objectives, wanted to promote language learning, but many times the social relations between Erasmus students from different countries are stronger than with the local population, thus increasing European cultural concept and use of English as the language of Europe. The program has created a common identity for those enjoying it and those locals whose classmates are from other parts of Europe. (Dervin, 2007) In terms of education, from a more academically approach, the Bologna process ensures comparability in the standards and quality of higher education qualifications all over Europe, harmonizing academic degree structures and standards as well as academic quality assurance throughout the EU Member States and in other European countries, going beyond the national borders.

The concept of solidarity inside the European Union is based on the idea of national solidarity already developed in all the European states. The need to balance the economic and social development inside the states drifted important amounts of economic resources from the most developed areas to those less fortunate. The philosophical approach to the system is based on the concept of a common society, where the members help each other, the wealthy helps the poor, the strong the weak. The social solidarity was united with the concept of nation, as a community of people sharing similar cultural values and in the case of the national state, also political rights and duties. The nation had the intellectual and emotional force to support the concept of social solidarity as the majority of the Europeans identified themselves as members of a national community. The European Union has developed an important action in this field through the structural funds, as the European Regional Development Fund, European Social Fund, the Cohesion Fund, and the Common Agriculture Policy now more focus on rural development rather than production subsidies. All these funds account for most of the European Union budget, being crucial in the creation of a common European identity. The previous national boundaries reasons cannot be used in the case of the European solidarity, being substituted by the concept of European unity and solidarity among its members. (Meehan, 2003, 174) The concept of European solidarity has created internal and international problems for the member states. The concept of cultural community in the EU is still not high enough to support the European solidarity. For example, the Catalan nationalism is strongly linked with the concept of the state solidarity, rejecting the idea of Spanish solidarity using Catalan financial resources because their identification with the Spanish nation is reduced. The main claim of the supporters of the independence for Catalonia is the use of the taxes collected in this territory in the solidarity of the Catalan nation, not beyond. Hence it is unacceptable a financial transfer to the less developed territories of Spain, a different cultural group. The same case can be found in Italy, where the North League claims a similar. On the European level, complaints about the European solidarity are numerous, as the Germans transferring funds to the less developed economies, as the Greek. (Streeck, 2000, 253) The German nation is seen as the limit of the solidarity, the financial support of West Germany to East Germany was accepted by a huge majority of the German citizens. But solidarity beyond the national boundaries rises much more concerns among the population. There are economic reasons for the solidarity, as the problems generated by the European Union interior market, the important profits for German companies due to their better economic performance, and the incapacity of the economic agents of the less developed countries to compete on equal terms because of their lower competitiveness (Michalski, 2006). But they are not a part of the debate for the general opinion on the national issue still dominates the concept of solidarity. The development of a higher level of identification among Europeans will decrease the tensions and improve the system at the European level.

\subsection{Indirect actions}

There have been different actions not initiated by the European Union institutions that have influenced the creation of a common identity as an embryo of the European nation. The sport has traditionally been a sphere of influence of nationalism. The idea of a sportsman or a sports club representing a wider community, a nation, has a great power of junction between citizens. 
Football as the most popular sport in Europe, and probably of the world, is an important force for the idea of belonging to a common space. The UEFA, Union of European Football Associations, and its main competitions, the Champions League and the Europa League, work as an addition to the national leagues, surpassing them in terms of audience and social importance in many European countries. Teams as Real Madrid, Manchester United, Bayern Munich or AC Milan go beyond the previous national borders with supporters all over Europe. The UEFA is an association independent from the European Union but was influenced by the European market and the principle of no discrimination because of the nationality (Briggs, 2005, 439). The Bosman ruling by the High Court of Justice of the EU abolished a previous regulation limiting the number of foreigners in the European teams, as no European citizen could be considered a foreigner inside the territory of the European Union. (Altbach, 2001, 525) It clearly broke the national spirit of the European football clubs and helped in the creation of a new level of identity, the European. Other sports as Basketball, Handball or Volleyball have followed the same development, becoming European rather regional. (Garcia, 2007) Perhaps the more obvious example in sports is the Ryder Cup, a golf tournament between the USA and the Europeans, conforming the first European national team competing internationally. Nevertheless, in terms of national teams, the European sport will surely follow the British model of different national teams inside the same political structure.

The power of the market-unifying rules and standards to abolish obstacles to trade is an important force homogenizing the Europeans, as the adoption of the metric system instead of the imperial units in the United Kingdom (Manners, 2002, 255-257). The treaty of accession to the European Economic Community, which the United Kingdom joined in 1973, obliged the country to incorporate into domestic law all EEC directives, including the use of a prescribed SI-based set of units for many purposes within five years. By 1980 most pre-packaged goods were sold using the prescribed units. Mandatory use of prescribed units for retail sales took effect in 1995 for packaged goods and in 2000 for goods sold loose by weight. Hence all the national differences inside the Union affecting trade must be abolished or respect the principle of proportionality to affect as less as possible the European trade. Obviously, this is an action focus on increasing the economic transactions in the European market by decreasing the national obstacles to trade but has had an important impact establishing common standards all over Europe, common understandings, common identity.

Eurovision, a song context, is also providing a common cultural association link with music, even though it includes countries whose Europeanisms is discussed, as Azerbaijan, Turkey, Russia or Israel. (Yair, 1993, 150-153) The song context counts with around 50 countries when the EU counts with 28 members currently. Nevertheless, every year an estimated amount of some 180 million viewers watch the Eurovision Song festival, and most winning songs were performed in English (26 times) reaffirming the dominance of the English language in Europe and creating a common cultural organization for Europe and its neighbors

The Council of Europe is an autonomous organization not belonging to the European Union. The organization promotes co-operation between European countries (versus integration in the EU) in the areas of legal standards, human rights, democratic development, the rule of law and cultural co-operation (Bjoernberg, 2007). It counts with 47 member states, 5 Council observers and 3 Assembly observers. Even though its real impact is much reduced due its cooperative soul without binding rule, it is a symbol of Europe, especially in the field of human rights. As the Organization for Economic Co-operation and Development (OECD), including 34 countries, most of them Europeans. It is a forum of countries describing themselves as committed to democracy and the market economy, providing a platform to compare policy experiences, seeking answers to common problems, identify good practices and coordinate domestic and international policies of its members. (Hyde-Price, 2000) Originally it was created to help administer the Marshall Plan, the American financial aid to Europe. The influence if the USA in the European commonality feeling can be also felt in the defense field, as NATO (Fierke, 1999, 732-733), the North Atlantic Treaty Organization. It works in practice as the European 
defense community, including USA, Canada, and Turkey.

Finally, the issue of an official language has been a crucial aspect in the creation of the national identity all over Europe. The state normally has promoted a normative approach to the official language eliminating the regional differences and dialects inside the territory, in cases like France, by direct legislation. Or in other national states by the economic predominance of the central area of the state normally also working as the publishing center of the state and hence most of the books edited in the country will follow the same language patterns eliminating regional differences. Another option chosen in more linguistically diverse countries has been including co-official languages as in the case of Spain, a country whose national identity was built by the state following the French tradition.

Obviously, the case of France cannot be used in the European Union, as there are around 150 regional and minority languages in Europe and 24 official and working languages in the EU. The coofficial system of Spain seems more appropriate, but raises concerns about what language should be chosen to be official all over the territory of the Union. The German language, with around 90 million speakers, is the most widely spoken mother tongue of Europe, but French has enjoyed traditionally a dominant role in the European institutions because of the importance of France in the genesis of the EU development and the previous role of the French language as a cultural and intellectual vehicle. But English, despite the cold involvement of UK in the process of European construction, has become the lingua franca of Europe, as more than $50 \%$ of the Europeans can communicate using it. (Hogan-Brun, 2009) Obviously, the lingua franca has been traditionally linked with a powerful nation dominating the European politics, as the Latin from the Roman Empire till the middle age, then the language of the Christian Church, French with the political power of the last Bourbons and the Napoleonic wars or English during the maximum splendor of the British Empire (Orwell, 2001). Currently, the importance of the English language is more link with the dominant position of the USA in the world politics. (Ammon, 2002) The English language is the sole official language of England and Gibraltar and one of the official languages of Ireland, Scotland, Wales, Malta, the Isle of Man, Jersey, Guernsey and the European Union; 13\% of EU citizens speak English as their native language. Another $38 \%$ of EU citizens state that they have sufficient skills in English to have a conversation, so the total reach of English in the EU is 51\% (Cenoz, 2000). Nevertheless, there are 34 official languages in the EU member states and 3 main working languages, French, German and English in the EU institutions. The importance of a common language, co-official to the native language of the Europeans, is basic to create a common identity (Phillipson, 2003), and hence should be promoted as sole working language of the EU, despite the opposition of Germans and French, as an act of social realism and a necessary measure to increase the European cohesion.

\section{CONCLUSIONS}

The European Union is reaching high levels of integration, the integration process has developed a new community strongly united in economic matters and more mildly in political affairs. Brexit will test the unity of Europe, as the UK is historical, economically and socially an important European country, but if the transition is successful it will probably trigger deeper integration in the EU in a very close future. The current European Union is just a transitional organization in the constant evolution towards a closer political Union. Primary the importance of economic issues in the process did not generate a problem of loyalty of the citizens involved in the process, but the current importance of political issues inside the European Union is growing higher suspicions by the main political subjects, the people, who somehow still feel attached to their national identity in terms of politics. Obviously, it is impossible to develop a common political system in Europe, the birthplace of democracy, without the European citizens, and their involvement and support can come just from a common European identity, a common cultural community of shared values, a common identification building a basic social cohesion. According to the French tradition, the nation can be created by the state, promoting and supporting actions to integrate the different subjects of the society but respecting their cultural differences, the Matryoshka doll model. The main problem 
applying this model, successfully implemented in many European states, as France, Spain or Italy, is that the European Union is not a real state, and hence it does not have the power, and the will, to implement the necessary measures in order to achieve the target of a new level of identity, the European nation. The most obvious parallel is the USA, a multinational state that from the federal level after the civil war confronting north and south, created the American nation, currently a strong link uniting the people of the States. This model is not desirable in Europe, as it assimilated the cultural differences into a new level of identity.

Nevertheless, the European Union has developed different areas in order to increase the common identity of the Europeans, as the creation of new symbols imitating the national building process of Europe, common political institutions, and other important achievements as the Schengen area and the common currency, or important advances in the field of common education. Other actions outside of the EU initiatives are uniting the European people, as sports or the use of English as the lingua franca of Europe, but still, the common cultural group of Europeans does not ha the enough power to transfer the loyalty of the citizens from the national level to the European level.

Supranationality has been used on many occasions at the European level, but the increased political integration needs or the support of the people, or the political maturity of the citizens by differencing nationality from citizenship. A combination of both aspects should be the way chosen by the European Union but the resistance of the national powers to lose their privileged position in our societies is a formidable obstacle.

The creation of a European nation, even if respecting the regional national identities, could generate new problems, as it can lead to a world confrontation. If the IIWW was a conflict of nations and the European Union a peace system breaking the political links between the nation and the state, the creation of the European nation could lead to major confrontations to other blocs or areas of the world reproducing the problem but in a bigger and more destructive scale.

On the other hand, a European nationalism could lead to the higher integration of immigrants in the European society, following the example of USA. A more cohesive society with wider cultural common values regardless the nationality could create common basic standards, easier to internalize for those who come to live in Europe, helping them to integrate into the European society. But it could also create negative side effects, as barriers for further enlargements of the European Union as the common European identity becomes stronger and more different from those outside the Union. It could increase the differences with the countries outside the Union unless they included in their identity the European culture, following the Transactional theory of integration.

The current model of the European Union and its relatively weak institutions will probably lead to a hybrid system of identification, where the local national identity will be still cohabitating with the European national identity, undermining the benefits of a common identity. New generations of Europeans have already a stronger European cultural identification and the foreseeable political development of the Union will require new measures to increase the involvement of the citizens in the process. Hence more drastic measures will be needed in the future promoting the creation of a strong European identity.

\section{WORKS CITED}

Altbach, P. G., \& Teichler, U. (2001). Internationalization and exchanges in a globalized university. Journal of Studies in International Education, 5(1), 5-25.

Amin, A. (2004). Multi-ethnicity and the idea of Europe. Theory, Culture \& Society, 21(2), 1-24.

Ammon, U., \& McConnell, G. D. (2002). English as an academic language in Europe. Frankfurt am Main: Peter Lang.

Atger, A. F. (2008). The Abolition of Internal Border Checks in an Enlarged Schengen Area: Freedom of movement or a scattered web of security checks? (Vol. 8). CEPS. 
Bauboeck, R. (1997). Citizenship and national identities in the European Union. Harvard Law School.

Bertozzi, S. (2008). Schengen: achievements and challenges in managing an area encompassing 3.6 million $\mathrm{km}^{2}$. CEPS Working Document. 284.

Briggs, L. V. (2005). UEFA v. The European Community: Attempts of the governing body of European soccer to circumvent EU Freedom of Movement and Antidiscrimination Labor Law. Chicago Journal of International Law. 6(1). 439.

Bruter, M. (2003). Winning Hearts and Minds for Europe - The Impact of News and Symbols on Civic and Cultural European Identity. Comparative political studies, 36(10), 1148-1179.

Bruter, M. (2008). Legitimacy, Euroscepticism \& identity in the European Union-problems of measurement, modeling \& paradoxical patterns of influence. Journal of Contemporary European Research, 4(4), 273-285.

Herdina, P., \& Jessner, U. (2000). The dynamics of third language acquisition. In Cenoz, J. \& Jessner, U. (Eds) English in Europe: The acquisition of a third language. Clevedon Hall, UK. 19, 84.

Chochia, A. (2012). The European Union and its Policy Towards the Neighbours from South Caucasus. United Europe, 6. 27.

Delanty, G. (1997). Models of citizenship: defining European identity and citizenship. Citizenship studies, 1(3), 285-303.

Dervin, F. (2007). The Erasmus experience: halcyon days of hypermodernity. Retrieved from: https://www.yumpu.com/en/document/view/31689510/the-erasmus-experience-halcyon-daysof-hypermodernity-fred-. (June 25, 2014).

Eder, K., \& Giesen, B. (2001). European Citizenship Between National Legacies and Postnational Projects. Oxford University Press.

Fierke, K. M., \& Wiener, A. (1999). Constructing institutional interests: EU and NATO enlargement. Journal of European Public Policy, 6(5), 721-742.

Garcia, B. (2007). UEFA and the European Union: from confrontation to co-operation?. UACES in association with the UACES Student Forum.

Grabbe, H. (2000). The sharp edges of Europe: extending Schengen eastwards. International Affairs, 76(3), 519-536.

Hedetoft, U. (1998). Political symbols, symbolic politics: European identities in transformation. Ashgate Pub Ltd.

Hogan-Brun, G., Mar-Molinero, C., \& Stevenson, P. (2009). Testing regimes: introducing cross-national perspectives on language, migration, and citizenship. In Discourses on Language and Integration - Critical perspectives on language testing regimes in Europe. Bristol. John Benjamins Publishing Company. doi: 10.1075/dapsac.33. 33, 1.

Hyde-Price, A. (2000). Germany and European order: Enlarging NATO and the EU. Manchester University Press.

Kaelble, H. (2003). European symbols, 1945-2000: concept, meaning, and historical change. n. a.

Kaelberer, M. (2004). The euro and European identity: symbols, power and the politics of European monetary union. Review of International Studies, 30(02), 161-178.

Kerikmae, T. (2009). Estonia in the European Legal System: Protection of the Rule of Law through Constitutional Dialogue. Tallinn University.

Kirch, A., Talts, M., \& Tuisk, T. (2004). The identity dynamics of the Estonians and the Russians living in Estonia before and after the EU referendum. Ethnicity studies 2004: Perceptions of European integration, 33-47.

Kohli, M. (2000). The battlegrounds of European identity. European Societies, 2(2), 113-137.

Luna-Arocas, R., Guzmán, G., Quintanilla, I., \& Farhangmehr, M. (2001). The Euro and European identity: the Spanish and Portuguese case. Journal of Economic Psychology, 22(4), 441-460. 
Maguire, J., \& Poulton, E. K. (1999). European Identity Politics in Euro 96 Invented Traditions and National Habitus Codes. International review for the sociology of sport, 34(1), 17-29.

Manners, I. (2002). Normative power Europe: a contradiction in terms?. JCMS: Journal of common market studies, 40(2), 235-258.

McLaren, L. (2005). Identity, interests and attitudes to European integration. Springer.

Meehan, E. (1993). Citizenship and the European community. The Political Quarterly, 64(2), 172-186.

Michalski, K. (Ed.). (2006). Conditions of European solidarity: What holds Europe together? (Vol. 1). Central European University Press.

Indivero, G. (2015). An Exploration of Unintended Consequences: The Relationship Between US Military Technologies and Risk Factors for PTSD in Soldiers (Doctoral dissertation, Wesleyan University).

Pascouau, Y. (2011). Schengen area under pressure: controversial responses and worrying signs. EPC Commentaries.

Risse, T., Engelmann-Martin, D., Knope, H. J., \& Roscher, K. (1999). To Euro or not to Euro? The EMU and identity politics in the European Union. European Journal of International Relations, 5(2), 147-187.

Risse, T. (2003). The Euro between national and European identity. Journal of European Public Policy, 10(4), 487-505.

Souto-Otero, M., Huisman, J., Beerkens, M., De Wit, H., \& Vujic, S. (2013). Barriers to international student mobility evidence from the Erasmus program. Educational Researcher, 42(2), 70-77.

Streeck, W. (2000). Competitive solidarity: Rethinking the European social model. Kontingenz und Krise: Institutionenpolitik in kapitalistischen und postsozialistischen Gesellschaften. Frankfurt aM: Campus, 245-262.

Teichler, U. (2001). Changes of Erasmus under the umbrella of Socrates. Journal of Studies in International Education, 5(3), 201-227.

Troitino, D. R., \& Chochia, A. (2012) The EU Foreign Affairs and the European Values. Dr. Nicoleta Vasilcovschi. L'Europe Unie / United Europe, (6) Retrieved from: http://www.upm.ro/cercetare/EuropeUnie/docs/L'Europe_Unie_Nr.6_2012.pdf\#page=4. 2 .

Troitino, D. R. (2013). The Current Economic Crisis of the EU: Genesis, Analysis, and Solutions. Baltic Journal of European Studies, 3(1), 6-28.

Troitino, D. R. (2013). European Integration: Building Europe (European Political, Economic, and Security Issues). Nova Science Publishers Incorporated.

Troitino, D. R. (2014). Europos Parlamentas: praeitis, dabartis ir ateitis. Teises apzvalga, 11(1), 5-24.

Troitino, D. R. (2014, 07 15). The European Commission and the management of Europe: past, present, and future. (Z. Čekerevac, Ed.) MEST Journal, 2(2), 241-250. doi: 10.12709/mest.02.02.02.24

Valasek, T. $(2007,12)$. The roadmap to better EU-NATO relations. London: Centre for European Reform, Briefing Note - Centre for European Reform. Retrieved from: https://www.cer.org.uk/sites/default/files/publications/attachments/pdf/2011/briefing_tv_eu_nat o_20dec07-1156.pdf

Vernygora, V. (2011). Discovering the Baltics? Think Tallinn! Perspectives for New Zealand in the Baltic States. University of Canterbury. Retrieved from: http://ir.canterbury.ac.nz/handle/10092/5301

Yair, G. (1995). 'Unite Unite Europe' The political and cultural structures of Europe as reflected in the Eurovision Song Contest. Social Networks, 17(2), 147-161.

\section{Funding}

This work was supported by the Jean Monnet module Functional Capacity of the European Union, under grant VERT672, European Community Framework Programme Erasmus + Jean Monnet. 
Received for publication:

Revision received:

Accepted for publication:
24.08.2016

23.09.2016

12.12.2016

\section{How to cite this article?}

Style - APA Sixth Edition:

Troitino, D. R. (2017, Jan 15). The European Union: The building of a nation. (Z. Cekerevac, Ed.) MEST Journal, 5(1), 119-134. doi:10.12709/mest.05.05.01.15

Style - Chicago Sixteenth Edition:

Troitino, David Ramiro. "The European Union: The building of a nation." Edited by Zoran Cekerevac. MEST Journal (MESTE) 5, no. 1 (Jan 2017): 119-134. doi:10.12709/mest.05.05.01.15

Style - GOST Name Sort:

Troitino David Ramiro The European Union: The building of a nation [Journal] // MEST Journal / ed. Cekerevac Zoran. - Belgrade - Toronto : MESTE, Jan 15, 2017. - 1 : Vol. 5. - pp. 119-134.

Style - Harvard Anglia:

Troitino, D. R., 2017. The European Union: The building of a nation. MEST Journal, 15 Jan, 5(1), pp. 119-134.

Style - ISO 690 Numerical Reference:

The European Union: The building of a nation. Troitino, David Ramiro. [ed.] Zoran Cekerevac. 1, Belgrade - Toronto : MESTE, Jan 15, 2017, MEST Journal, Vol. 5, pp. 119-134. 